\title{
REFERENCES TO W. MORGAN
}

(To the Editors of the Journal of the Institute of Actuaries)

DEAR Sirs,

(1) William Morgan, F.R.S., I750-I833.

(2) Arthur Morgan, F.R.S., I800-1870.

(3) William Morgan, $\quad 183^{1-1897 . ~}$

In the index to the first twenty volumes of the fournal there are six references to Morgan of which the first four apply to (r), the best known actuary of that name. The quotation by Spens in Vol. x, p. 66, should refer to his son Arthur Morgan (2), and the letter in Vol. XII, p. 235, was by William Morgan's grandson (3). The index to the first forty volumes reduces the number of references to three all indexed under "Morgan (W)." The first is the Spens reference to Arthur Morgan, the second refers to William Morgan and the third to the letter by his grandson. There are also un-indexed references to the Morgans in the fournals.

Yours faithfully,

W. PALIN ELDERTON

i9 Coleman Street

E.C. 2

${ }_{23}$ rd December, $193 \mathbf{I}$ 